\title{
HIV testing in Scotland: Are we meeting the standard? \\ BASHH Scotland National Audit 2004
}

\author{
Fiona Ross, Deborah Wardle, Alison Currie, Steve Baguley
}

May 2005

1. Introduction

1.1 A quarter of HIV positive people in the UK are undiagnosed ${ }^{1}$. Early diagnosis improves prognosis and reduces onward transmission but despite this, many people remain untested $^{2}$. Previous audits have revealed great variation in HIV testing even in Genitourinary Medicine (GUM) clinics ${ }^{3}$, where most of the voluntary testing in the UK takes place. Many Sexually Transmitted Infections (STIs) increase the transmission of HIV.

In light of the above, the draft Scottish Sexual Health Strategy (2003) proposed that:

“...HIV testing [should be] offered to all GUM clinic attendees not known to be HIV infected who present with a new STI. ... Reasons for non-uptake should be recorded." This standard was retained in the final document. ${ }^{4}$

1.2 The English Sexual Health Strategy (2001) set different standards.

"by the end of 2004, all ... attendees should be offered an HIV test on their first screening for sexually transmitted infections ... with a view to: increasing the uptake of the test ... to $40 \%$ by the end of 2004 and to $60 \%$ by the end of 2007 ".5

1.3 In order to provide an understanding of testing policy prior to the publication of the Scottish Sexual Health Strategy we undertook an audit of practice in Scottish GUM clinics.

\section{Method}

2.1 Twelve clinic areas were identified (Ayrshire, Argyll \& Clyde, Grampian, Borders, Dumfries \& Galloway, Lothian, Fife, Greater Glasgow, Highland, Lanarkshire, Forth valley and Tayside) and audited between August 2004 and February 2005. If an area had several clinics, notes were audited from one site as long as the staff that worked in each clinic were the same and using the same protocols. It was agreed that results would be anonymised in the audit report although each clinic would be aware of their own performance.

We audited practice in three key patient groups:

- New attendees

- Patients deemed to be at increased risk of having HIV

- Patients with a newly diagnosed STI

Our audit questions were:

What proportion of people in these groups was offered an HIV test? 
What proportion of those who were offered a test, had a test?

What proportion of people in these groups had a test?

We also audited clinic policy on documenting why patients are declining HIV testing. In addition to the audit we interviewed a health advisor or clinician to ascertain each department's policy on HIV testing. (See Appendix 2)

2.2 FR, DW and AC reviewed the notes of the first 100 first time attendees (or 50 if a small clinic) who registered from the $1^{\text {st }}$ March 2004. Patients with no conceivable risk and those known to be HIV positive were excluded. Data regarding age, sex, risk group, STI diagnosis, whether offered an HIV test, whether accepted a test, reason for declining a test were entered into a Microsoft (MS) Excel spreadsheet (See Appendix 1). The results were analysed using MS Excel. For the purposes of analysis, each clinic area was given a number. Lead clinicians have been told which number represents their clinic.

2.3 The database and questionnaire were piloted at the Aberdeen GUM clinic. 


\section{Results (see appendix 4 for data tables)}

Of 1137 sets of notes reviewed, 15 were excluded because they had recently had an HIV test and had had no risk since then, 5 were excluded because they had recently donated blood and had had no risk since then, 6 were excluded because they were virginal and had no other risks and 6 were excluded for other reasons including being HIV positive. There were thus 1105 eligible new attendees.

\subsection{New Attendees}

The proportion of patients offered a test varied from 5.1\% (5/98) to $95.8 \%(92 / 96)$ with a national average of $66.4 \%$ (734/1105). The proportion actually having a test varied between 5.1\% (5/98) and 72.9\% (70/96) with a national average of 43.8\% (484/1105).

(Figure 1)

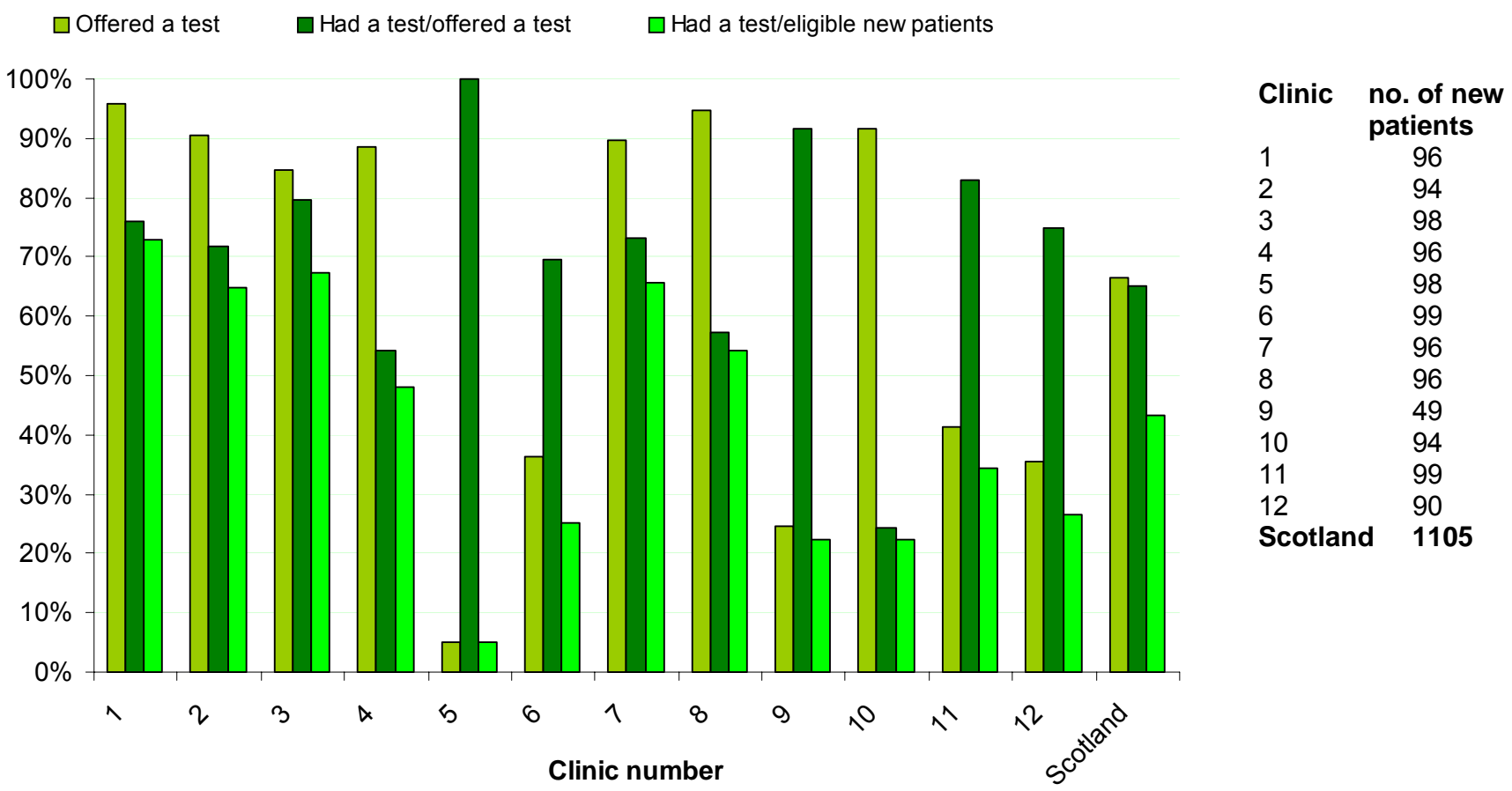

Figure 1. The percentage of new attendees that were offered an HIV test, the percentage of those offered a test who accepted one and the percentage of new attendees that had an HIV test.

For example: in clinic 1, of the 96 eligible new attendees 92 (95.8\%) were offered a test. Of these 92 patients 70 (76.1\%) accepted a test resulting in $72.9 \%$ of all eligible new attendees having an HIV test. 


\subsection{Patients in a Risk Group}

Patients in the audit were identified as being in a risk group after reviewing their notes. Of the 1105 eligible new attendees, 109 were deemed to be at increased risk of HIV. The number of people in each risk group is shown in the table.

\begin{tabular}{lc}
\hline Risk group & Number of people \\
No increased risk identified & 1028 \\
MSM & 26 \\
MSM contact & 3 \\
IDU & 15 \\
IDU contact & 21 \\
Contact from high prevalence country & 19 \\
CSW & 2 \\
CSW contact & 12 \\
Sexual assault & 6 \\
Non-professional piercing/tattoo & 2 \\
Other & 19 \\
\hline
\end{tabular}

The proportion offered a test varied between $57.1 \%$ and $100 \%$. With the Scottish average being $94.3 \%$

The proportion actually having a test varied between $57.1 \%$ and $100 \%$. With a mean of 79.2\% (84/106). (Fig 2)

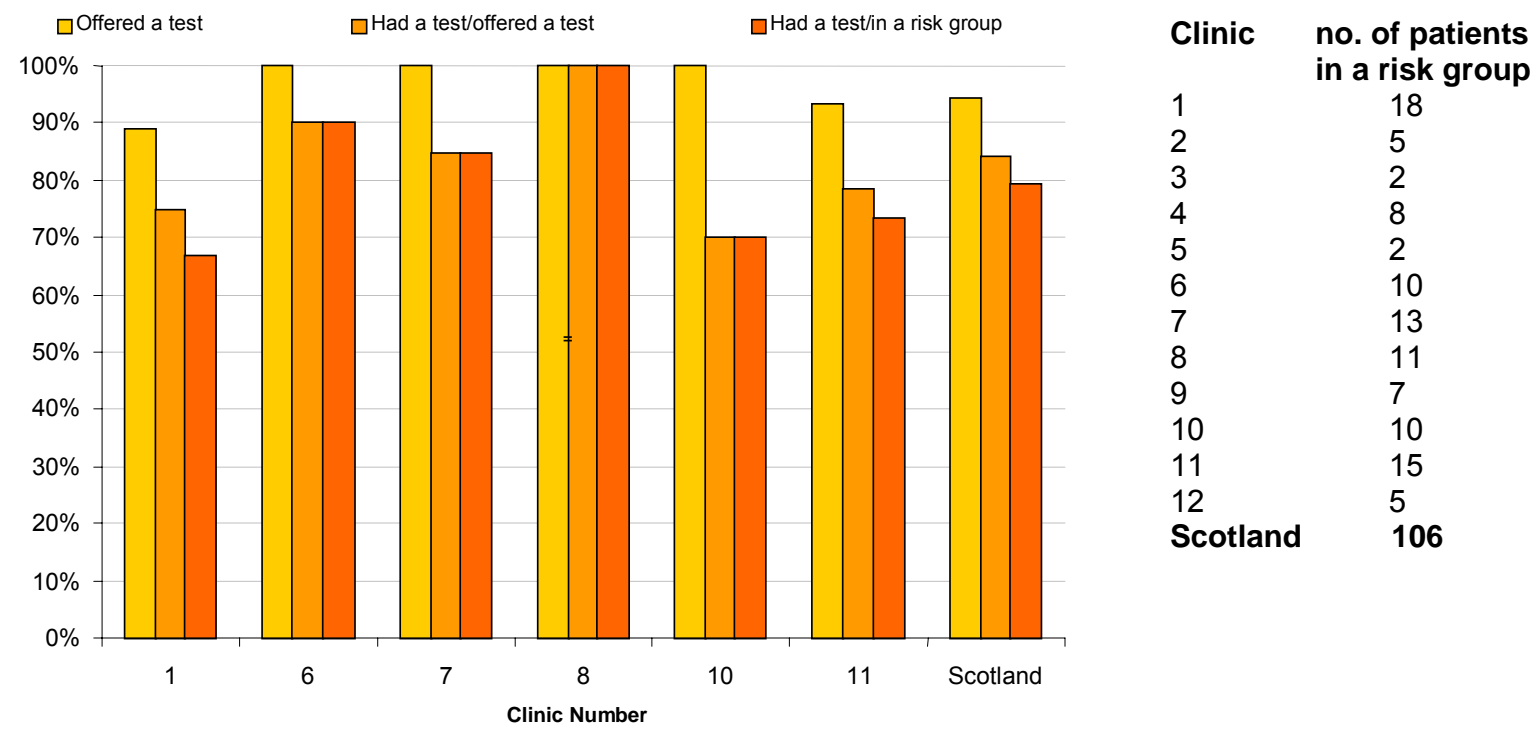

Figure 2. The percentage of people in a risk group that were offered a test, the proportion of those offered a test who accepted one and the overall proportion of people in a risk group that had an HIV test. (Clinics where fewer than 10 people were in a risk group have been excluded from the chart).

For example: in clinic 1, of the 18 eligible new attendees in a risk group 16 (88.9\%) were offered a test. Of these 16 patients 12 (75\%) accepted a test resulting in $66.7 \%$ of all eligible new attendees in a risk group having an HIV test. 


\subsection{People with a newly diagnosed STI}

Five hundred and three patients were identified as having a STI. In individual clinics the proportion of people offered a test varied from 0\% to 97.0\%. Across Scottish GU clinics as a whole 307/503 (61.4\%) of patients were offered an HIV test.

The proportion who actually had a test varied from $14.3 \%$ to $69.7 \%$ with an overall figure of 181/503 (35.8\%). (Figure 3).

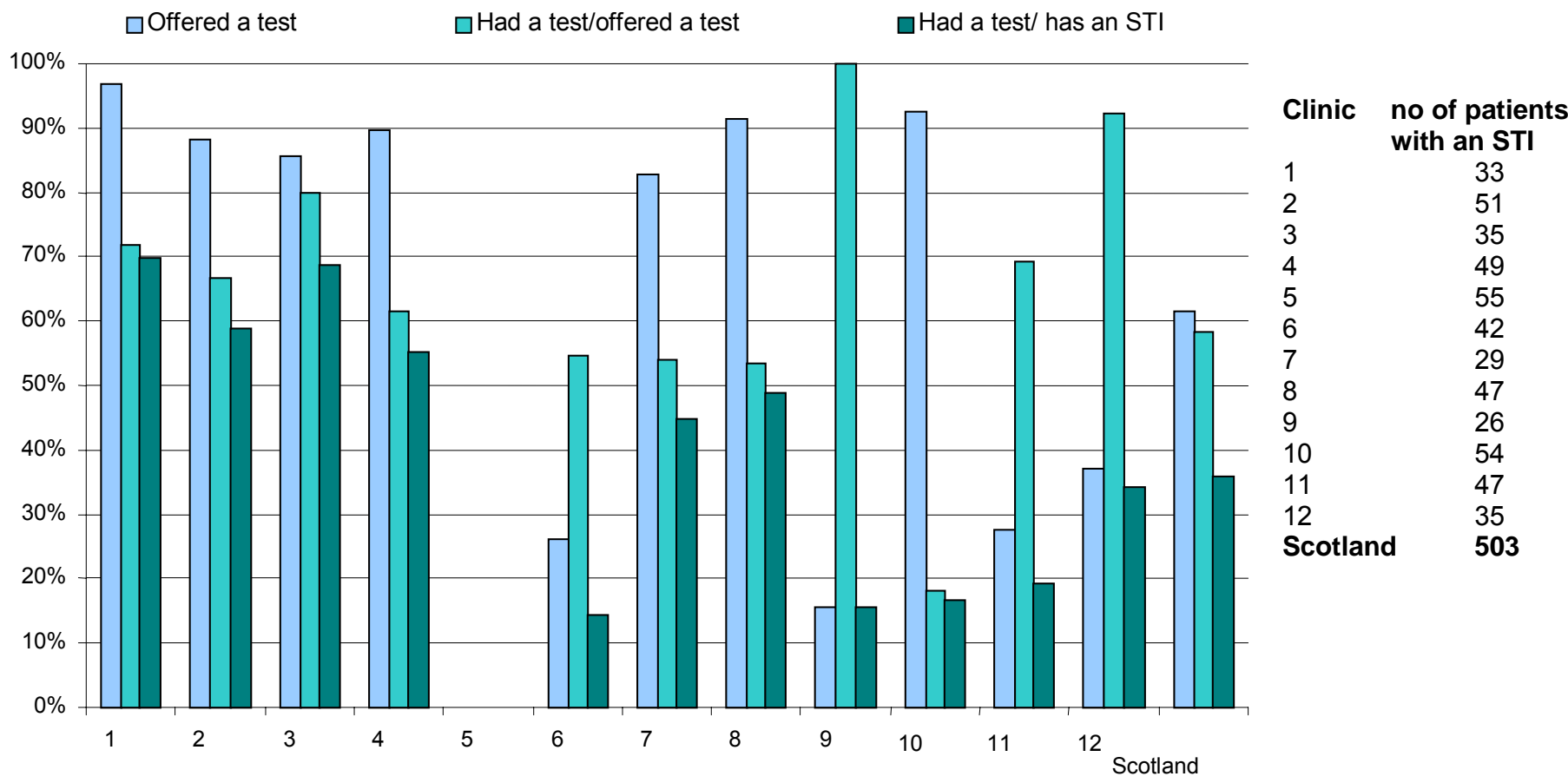

\section{Clinic number}

Figure 3. The proportion of people with an STI that were offered an HIV test, the proportion of those who accepted one and the proportion of people with an STI that had a test. (No tests were offered by clinic 5).

For example: in clinic 1, of the 33 eligible new attendees with a new STI, 32 (97\%) were offered a test. Of these 32 patients 23 (71.9\%) accepted a test resulting in $69.7 \%$ of all eligible new attendees with a new STI having an HIV test. 


\subsection{Documentation of Reason for declining testing}

Of the 257 people who declined a test when offered one, their reason for declining was documented in $28 \%$ of cases (range $0 \%$ to $100 \%$ ). (Fig 4 )

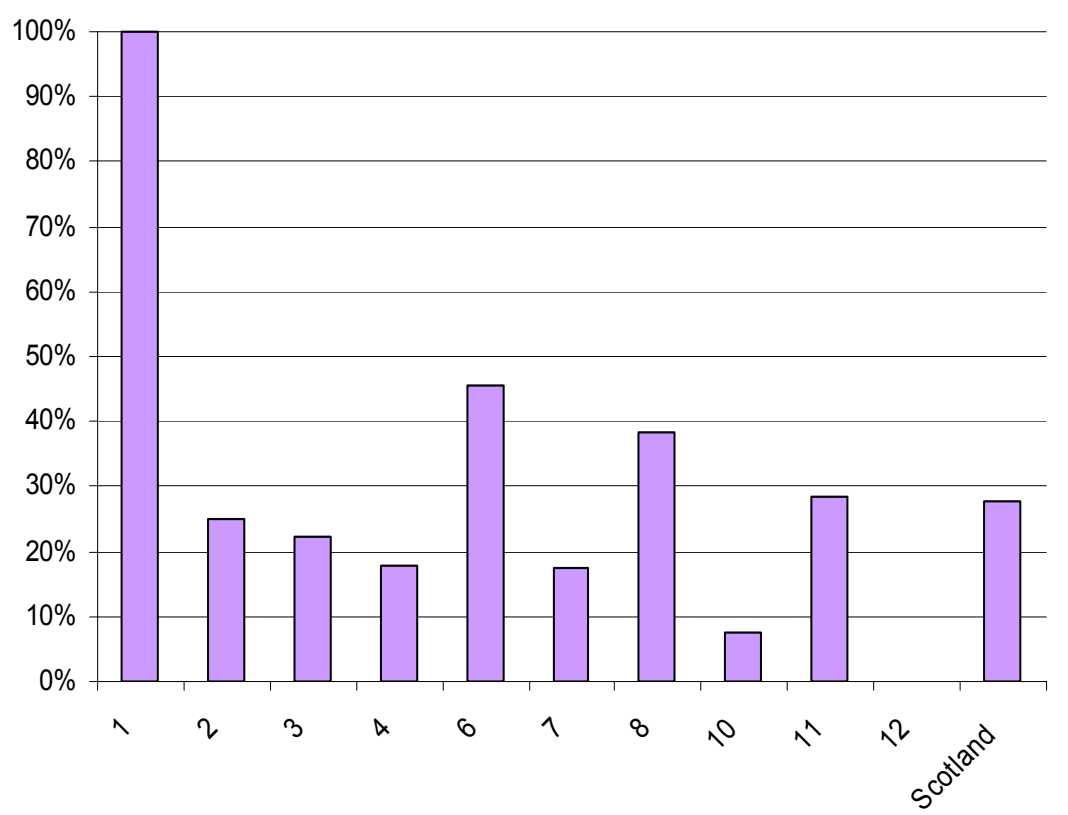

$\begin{array}{ccc}\text { clinic } & \begin{array}{l}\text { number } \\ \text { who } \\ \text { declined } \\ \text { a test }\end{array} & \begin{array}{l}\text { number where a } \\ \text { reason for } \\ \text { declining was } \\ \text { documented }\end{array} \\ 1 & 22 & 22 \\ 2 & 24 & 6 \\ 3 & 18 & 4 \\ 4 & 39 & 7 \\ 5 & 0 & 0 \\ 6 & 11 & 5 \\ 7 & 23 & 4 \\ 8 & 39 & 15 \\ 9 & 1 & 1 \\ 10 & 65 & 5 \\ 11 & 7 & 2 \\ 12 & 8 & 0 \\ \text { Scotland } & 257 & \\ & & \end{array}$

Figure 4. Proportion of people declining a test who had their reason(s) for declining recorded (clinics where fewer than 5 people declined a test have been excluded from the chart). 


\subsection{Questionnaire results}

Below is a tabulated summary of the questionnaire results.

\begin{tabular}{|c|c|c|c|c|c|}
\hline $\begin{array}{l}\text { Clinic } \\
\text { No. }\end{array}$ & Testing Policy & $\begin{array}{l}\text { Opt inl } \\
\text { opt out }\end{array}$ & $\begin{array}{l}\text { Method for giving } \\
\text { results: Increased } \\
\text { risk }\end{array}$ & $\begin{array}{l}\text { Method for } \\
\text { giving results: } \\
\text { Low risk }\end{array}$ & $\begin{array}{l}\text { Any policy } \\
\text { changes } \\
\text { planned? }\end{array}$ \\
\hline 1 & $\begin{array}{l}\text { All patients unless no } \\
\text { conceivable risk }\end{array}$ & Opt in & HA/Dr appointment & $\begin{array}{l}\text { Patient phones } \\
\text { for result }\end{array}$ & No \\
\hline 2 & $\begin{array}{l}\text { All patients unless no } \\
\text { conceivable risk }\end{array}$ & Opt out & HA Appointment & $\begin{array}{l}\text { Patient phones } \\
\text { for result/ No } \\
\text { result given if } \\
\text { negative } \\
\end{array}$ & No \\
\hline 3 & $\begin{array}{l}\text { All patients unless no } \\
\text { conceivable risk }\end{array}$ & Opt in & HA Appointment & $\begin{array}{l}\text { Patient phones } \\
\text { for result }\end{array}$ & No \\
\hline 4 & $\begin{array}{l}\text { All patients unless no } \\
\text { conceivable risk }\end{array}$ & Opt in & HA Appointment & $\begin{array}{l}\text { Phone result from } \\
\text { HA }\end{array}$ & No \\
\hline 5 & $\begin{array}{l}\text { Only those patients } \\
\text { requesting a test }\end{array}$ & Opt in & Dr Appointment & $\begin{array}{l}\text { Patient phones } \\
\text { for result }\end{array}$ & No \\
\hline 6 & $\begin{array}{l}\text { High Risk patients } \\
\text { and those requesting } \\
\text { a test }\end{array}$ & Opt in & HA Appointment & HA Appointment & No \\
\hline 7 & $\begin{array}{l}\text { All patients unless no } \\
\text { conceivable risk }\end{array}$ & Opt in & HA Appointment & Letter & Yes \\
\hline 8 & $\begin{array}{l}\text { All patients unless no } \\
\text { conceivable risk }\end{array}$ & Opt in & HA Appointment & $\begin{array}{l}\text { Patient phones } \\
\text { for result/ No } \\
\text { result given if } \\
\text { negative }\end{array}$ & Yes \\
\hline 9 & $\begin{array}{l}\text { All patients unless no } \\
\text { conceivable risk }\end{array}$ & Opt in & $\begin{array}{l}\text { HA Appointment/ } \\
\text { Phone if traveling } \\
\text { long distances }\end{array}$ & $\begin{array}{l}\text { Patient phones } \\
\text { for result }\end{array}$ & Yes \\
\hline 10 & $\begin{array}{l}\text { All patients unless no } \\
\text { conceivable risk }\end{array}$ & Opt out & HA Appointment & $\begin{array}{l}\text { Patient phones } \\
\text { for result }\end{array}$ & Yes \\
\hline 11 & $\begin{array}{l}\text { All patients unless no } \\
\text { conceivable risk }\end{array}$ & Opt in & Dr Appointment & $\begin{array}{l}\text { Patient phones } \\
\text { for result }\end{array}$ & Yes \\
\hline 12 & $\begin{array}{l}\text { High Risk patients } \\
\text { and those requesting } \\
\text { a test }\end{array}$ & Opt in & HA Appointment & $\begin{array}{l}\text { Patient phones } \\
\text { for result/ No } \\
\text { result given if } \\
\text { negative }\end{array}$ & Yes \\
\hline
\end{tabular}

All the clinics except one were using paper notes only with the one clinic using paper and computer notes.

There were several clinics that were planning changes to their current policy of offering or giving results. These included:

- Changing to an "opt out" system where the patient reads a leaflet in the waiting room and if then tested it is assumed that PTC has been completed. (Clinics 8 \& 11)

- $\quad$ Starting to offer all patients an HIV test. (clinic12)

- Changing to an “opt out" system (clinic 12)

- Updating the written information given to patients 
- Integrating with Family Planning services and increasing testing (clinic10)

- Introducing an automated result service for low risk patients. (clinic 7)

There were several problems that clinics reported with their current systems:

- Having to give positive results and finding contact details are wrong (clinic 1)

- Limited access to electronic results as only the MLSO has computer access (clinic 2)

- Difficulties in contacting the low risk patient who is HIV positive (clinic 7)

- Long waiting list for out patient appointments that are deterring patients from testing (clinic 11)

- Not enough Health Advisers for Pretest discussion (clinics 10 and 6)

- No funding available to increase testing (clinic 6)

\section{Discussion}

4.1 Scotland is meeting the English sexual health strategy standard for testing new attendees and most people in a risk group are also being offered a test. However the audit has shown that in the year prior to the launch of the Scottish Sexual Health Strategy we fell far short of offering all patients with a new STI an HIV test. Throughout the country there is dramatic variation in both the proportion of patients being offered a test and actual uptake of HIV testing.

4.2 This is the first national audit to compare testing practice against the 'STI standard'. Because the information was derived from a notes review we were able to exclude people who did not need an HIV test (for example recent blood donation) and thus the results are more meaningful than those derived merely from surveillance codes.

4.3 As with any audit there may be some inaccuracies. There were three auditors and hence the possibility for interauditor variability although where possible, clinics were audited by two people. It had been intended that auditors would enter data directly into a MS Excel spreadsheet but due to limited access to computers most data were initially entered onto paper and then transcribed into the spreadsheet later. Thus there was the potential for transcription errors. The sample size (particularly for the patients in a risk group) from some centres was quite small thus the confidence intervals (not shown) will be quite wide.

Each clinic uses a different method of recording histories and consequently risk. It was not always possible to tell from the notes whether a full risk assessment had been taken.

4.4 Although the target of $100 \%$ offering is perhaps unachievable, many clinics have potential to improve significantly. Four clinics showed through their answers to the questionnaire that their protocols did not to target people with STIs. Eight clinics had a policy of offering tests to all patients but they were not actually doing this. This may be due to poor documentation of the offer or a problem with staff interpretation of policy. The usefulness of the widely adopted terms 'opt out' and 'opt in' is questionable - it is generally assumed that an "opt out" system results in more testing but it appears that this is not necessarily the case. For example compare results for Clinic 1 (opt in) and Clinic 4 (opt out). It may be that each individual's definitions of these terms are different.

The English Health Protection Agency recently defined these terms as: 
"Opt in: an HIV test is offered on its own or as an optional addition to a sexual health screen (SHS). The patient must actively agree to the test as an extra to the SHS.

Opt out: an HIV test forms part of the SHS and is routinely offered and carried out unless the patient declines. The patient must actively refuse an HIV test otherwise it is done automatically (informed consent via leaflet or discussion is presumed)."

4.5 These findings will inform future developments to meet the standards set by the Scottish sexual health strategy.

\section{Recommendations}

5.1 Scottish GUM departments should adopt the policy that all patients with a new STI and those in risk groups should be offered HIV testing.

5.2 When patients decline a test their reason for declining should be documented.

5.3 Many people find the terms "opt in" and "opt out” confusing so their use should be discontinued.

5.4 GUM departments could adopt a standard risk assessment proforma (for example see Appendix 3). This will save time and encourage a full and consistent risk assessment to be made in each clinic setting.

5.5 Some clinics have said that they are limited in the amount of "low risk" testing they can do by funding problems. Where lack of resources is perceived to be a problem this should be addressed at NHS board level, if necessary with the support of BASHH. Sexual Health Strategy spending plans need to include funding for increased testing.

5.6 Clinics should use the ISD service codes as a quick way to assess their HIV testing practice. However note that this will consistently underestimate activity because it will not take into account those who were ineligible for testing. In this audit 1 to $6 \%$ of patients did not need to be offered a test.

\section{Acknowledgments}

Clerical and clinical staff from all clinics audited.

Andy Winter for advice on audit design and reviewing the manuscript. 


\section{References}

1. The UK Collaborative Group for HIV and STI Surveillance. Focus on Prevention. HIV and other Sexually Transmitted Infections in the United Kingdom in 2003. London: Health Protection Agency Centre for Infections. November 2004. 17-19

2. McGarrigle CA, Mercer CH, Fenton KA, Copas AJ, Wellings K, Erens B, Johnson AM. Investigating the relationship between HIV testing and risk behaviour in Britain: National Survey of Sexual Attitudes and Lifestyles 2000. AIDS. 2005 Jan 3;19(1):77-84

3. Abubakar I, Bracebridge S, Willocks L. Monitoring the uptake of HIV testing among first attendees at GUM clinics in the East of England region. Commun Dis Public Health. 2004 Sep;7(3):212-5.

4.Scottish Executive Health Department. Respect and Responsibility; Strategy and Action Plan for Improving Sexual Health. Scottish Executive, Edinburgh Jan 2005.

5. Department of Health. Better prevention, Better services, Better sexual health: The national strategy for sexual health and HIV. 2001 


\section{Appendix 1 - Spreadsheet and codes used.}

\begin{tabular}{|r|r|r|l|l|l|l|l|l|l|l|}
\hline $\begin{array}{l}\text { record } \\
\text { number }\end{array}$ & sex & age & $\begin{array}{l}\text { Risk } \\
\text { group }\end{array}$ & $\begin{array}{l}\text { lffered } \\
\text { HIV test }\end{array}$ & $\begin{array}{l}\text { HIV test } \\
\text { not } \\
\text { indicated** }\end{array}$ & $\begin{array}{l}\text { reason } \\
\text { had HIV } \\
\text { test }\end{array}$ & $\begin{array}{l}\text { lor not } \\
\text { having } \\
\text { HIV test }\end{array}$ & $\begin{array}{l}\text { HIV test } \\
\text { result }\end{array}$ & STI 1 & STI 2 \\
\hline 1 & 1 & 22 & 1 & 2 & & & & & & 2 \\
\hline 2 & 1 & 17 & 1 & 1 & & 1 & & 2 & & 1 \\
\hline
\end{tabular}

$\begin{array}{ll} & \text { Sex } \\ 1 & \text { male } \\ 2 & \text { female }\end{array}$

Test offered

1 yes

2 no

3 Not applicable

test not indicated

1 done recently and no new risks

2 virgin and no other risk

3 recent blood donation

4 other

reason for not having test

1 not documented

2 feels at low risk:

3 needlephobic

4 deferred but DNA'd doesn't want to

5 know

6 couldn't cope with wait

7 other risk group

1 no increased risk identified

2 MSM

3 MSM contact

4 IDU

5 IDU contact

6 sex in high prevalence country

7 CSW

8 CSW contact

9 other

\section{STI}

1 none

$2 \mathrm{Ct}$

$3 \mathrm{Ng}$

4 TV

5 syph

6 warts

7 HSV

8 other 


\section{Appendix 2 - Questionnaire for Health Advisers}

Position:

Clinic:

Date:

1. What is your Policy on who should be offered an HIV test?
All patients (unless no conceivable risk of infection)
Patients in an increased risk group
Patients who ask for a test only
The decision is up to the individual clinician

2. Do you define your policy as opt in or opt out?

Opt in

Opt out

3. Do you use a leaflet to give information about HIV testing?

Yes

No

4. What notes system do you use

Electronic

Paper

5. Which methods do you use to give results? Does it vary with risk group?

Increased Risk. Method(s) used:

Low Risk. Method(s) used:

6. Are there any problems with the current system?

7. Do you intend changing your policy for offering a test or giving results? 


\section{Appendix 3 - example BBV risk history, assessment and pretest discussion proforma (female version)}

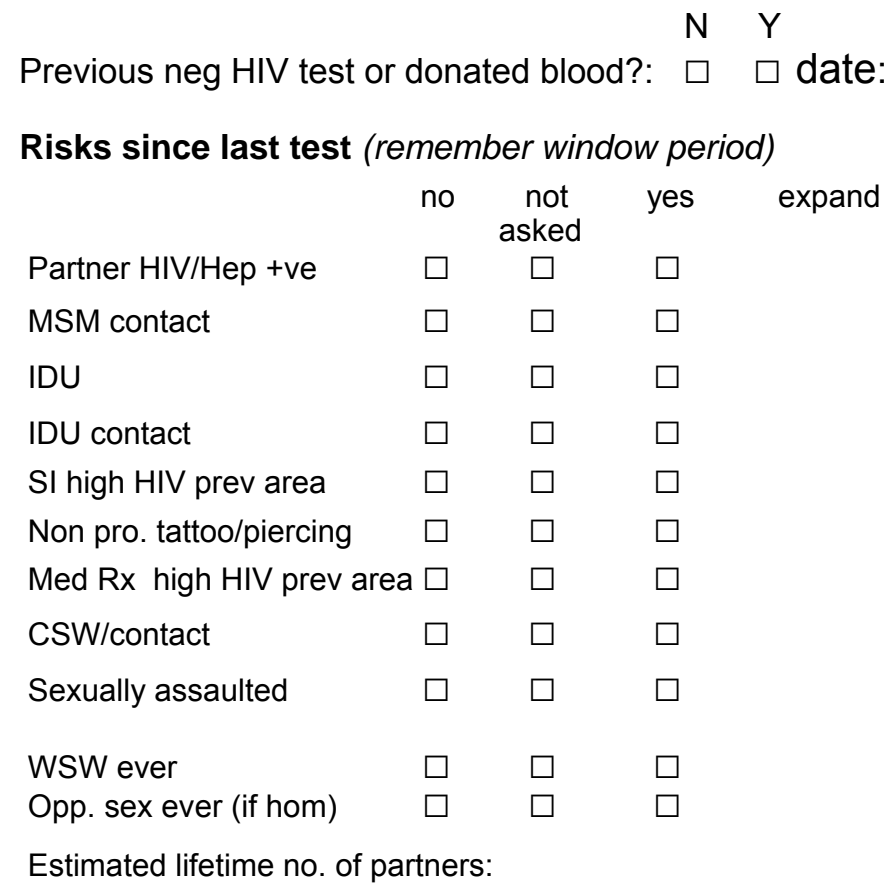

Risk assessed as:

Negligible

Low

Increased

\section{Pre HIV test discussion}

Read leaflet

Discussed window period

Discussed individual risk

$\mathrm{Y} N$

Offered HIV test?

If no, why?

Negligible risk and unconcerned Other:

\section{Outcome}

Will have test today

Will defer test

Declined test

Reason for declining:

Feels at low risk

Needlephobic

Other: 



\section{Appendix 4 - Data tables}

\begin{tabular}{|c|c|c|c|c|c|c|c|}
\hline 2 & 100 & 94 & 85 & $90.4 \%$ & 61 & $71.8 \%$ & $64.9 \%$ \\
\hline 3 & 100 & 98 & 83 & $84.7 \%$ & 66 & $79.5 \%$ & $67.3 \%$ \\
\hline 4 & 100 & 96 & 85 & $88.5 \%$ & 46 & $54.1 \%$ & $47.9 \%$ \\
\hline 7 & 98 & 96 & 86 & $89.6 \%$ & 63 & $73.3 \%$ & $65.6 \%$ \\
\hline 8 & 100 & 96 & 91 & $94.8 \%$ & 52 & $57.1 \%$ & $54.2 \%$ \\
\hline 9 & 50 & 49 & 12 & $24.5 \%$ & 11 & $91.7 \%$ & $22.4 \%$ \\
\hline 10 & 97 & 94 & 86 & $91.5 \%$ & 21 & $24.4 \%$ & $22.3 \%$ \\
\hline 11 & 100 & 99 & 41 & $41.4 \%$ & 34 & $82.9 \%$ & $34.3 \%$ \\
\hline 12 & 94 & 90 & 32 & $35.6 \%$ & 24 & $75.0 \%$ & $26.7 \%$ \\
\hline
\end{tabular}

\section{People in a risk group}

\begin{tabular}{|c|c|c|c|c|c|c|}
\hline Clinic & $\begin{array}{c}\text { Number of eligible } \\
\text { patients in risk groups }\end{array}$ & $\begin{array}{l}\text { Number } \\
\text { offered a } \\
\text { test }\end{array}$ & $\begin{array}{c}\text { Proportion } \\
\text { offered a test }\end{array}$ & $\begin{array}{c}\text { Number } \\
\text { who had a } \\
\text { test }\end{array}$ & $\begin{array}{c}\text { Proportion of those } \\
\text { offered a test who } \\
\text { had a test }\end{array}$ & $\begin{array}{c}\text { Proportion of eligible } \\
\text { patients in a risk group } \\
\text { who had a test }\end{array}$ \\
\hline 1 & 18 & 16 & $88.9 \%$ & 12 & $75.0 \%$ & $66.7 \%$ \\
\hline 2 & 5 & 5 & $100.0 \%$ & 4 & $80.0 \%$ & $80.0 \%$ \\
\hline 3 & 2 & 2 & $100.0 \%$ & 2 & $100.0 \%$ & $100.0 \%$ \\
\hline 4 & 8 & 8 & $100.0 \%$ & 6 & $75.0 \%$ & $75.0 \%$ \\
\hline 5 & 2 & 2 & $100.0 \%$ & 2 & $100.0 \%$ & $100.0 \%$ \\
\hline 6 & 10 & 10 & $100.0 \%$ & 9 & $90.0 \%$ & $90.0 \%$ \\
\hline 7 & 13 & 13 & $100.0 \%$ & 11 & $84.6 \%$ & $84.6 \%$ \\
\hline 8 & 11 & 11 & $100.0 \%$ & 11 & $100.0 \%$ & $100.0 \%$ \\
\hline 9 & 7 & 4 & $57.1 \%$ & 4 & $100.0 \%$ & $57.1 \%$ \\
\hline 10 & 10 & 10 & $100.0 \%$ & 7 & $70.0 \%$ & $70.0 \%$ \\
\hline 11 & 15 & 14 & $93.3 \%$ & 11 & $78.6 \%$ & $73.3 \%$ \\
\hline 12 & 5 & 5 & $100.0 \%$ & 5 & $100.0 \%$ & $100.0 \%$ \\
\hline Scotland & 106 & 100 & $94.3 \%$ & 84 & $84.0 \%$ & $79.2 \%$ \\
\hline
\end{tabular}

\section{People with an STI}

\begin{tabular}{|c|c|c|c|c|c|c|}
\hline $\begin{array}{c}\text { Clinic } \\
\text { number }\end{array}$ & $\begin{array}{c}\text { Number of eligible } \\
\text { patients with an STI }\end{array}$ & $\begin{array}{l}\text { Number } \\
\text { offered a } \\
\text { test }\end{array}$ & $\begin{array}{c}\text { Proportion } \\
\text { offered a test }\end{array}$ & $\begin{array}{c}\text { Number } \\
\text { who had a } \\
\text { test }\end{array}$ & $\begin{array}{l}\text { Proportion of those } \\
\text { offered a test who } \\
\text { had one }\end{array}$ & $\begin{array}{c}\text { Proportion of eligible } \\
\text { patients with an STI who } \\
\text { had a test }\end{array}$ \\
\hline 1 & 33 & 32 & $97.0 \%$ & 23 & $71.9 \%$ & $69.7 \%$ \\
\hline 2 & 51 & 45 & $88.2 \%$ & 30 & $66.7 \%$ & $58.8 \%$ \\
\hline 3 & 35 & 30 & $85.7 \%$ & 24 & $80.0 \%$ & $68.6 \%$ \\
\hline 4 & 49 & 44 & $89.8 \%$ & 27 & $61.4 \%$ & $55.1 \%$ \\
\hline 5 & 55 & 0 & $0.0 \%$ & 0 & $0.0 \%$ & $0.0 \%$ \\
\hline 6 & 42 & 11 & $26.2 \%$ & 6 & $54.5 \%$ & $14.3 \%$ \\
\hline 7 & 29 & 24 & $82.8 \%$ & 13 & $54.2 \%$ & $44.8 \%$ \\
\hline 8 & 47 & 43 & $91.5 \%$ & 23 & $53.5 \%$ & $48.9 \%$ \\
\hline 9 & 26 & 4 & $15.4 \%$ & 4 & $100.0 \%$ & $15.4 \%$ \\
\hline 10 & 54 & 50 & $92.6 \%$ & 9 & $18.0 \%$ & $16.7 \%$ \\
\hline 11 & 47 & 13 & $27.7 \%$ & 9 & $69.2 \%$ & $19.1 \%$ \\
\hline 12 & 35 & 13 & $37.1 \%$ & 12 & $92.3 \%$ & $34.3 \%$ \\
\hline Scotland & 503 & 309 & $61.4 \%$ & 180 & $58.3 \%$ & $35.8 \%$ \\
\hline
\end{tabular}

